\title{
The Step Wise Effect of Vessel Ligation Method on Intra and Postoperative Hypoparathyroidism in the Total Thyroidectomy
}

\author{
Total Tiroidektomide Vasküler Ligasyon Yönteminin İntraoperatif ve \\ Postoperatif Hipoparatiroidizme Aşamalı Etkisi
}

\section{(Dülçin Ercan1, (D Meltem Küçükyılmaz², (D) Hakan Yiğitbaş¹, (D) Nadir Adnan Hacım¹, (D Serhat Meriç1, (D) Ramazan Kuşaslan³, (D Yüksel Altınel1, (D) Merve Tokoçin¹, (D Tülin Saraç4, (D) Yeşim Erbil5}

${ }^{1}$ University of Health Sciences Turkey, Bağcllar Training and Research Hospital, Clinic of General Surgery, İstanbul, Turkey

2İstanbul Mehmet Akif Ersoy Thoracic and Cardivascular Surgery Training and Research Hospital, Clinic of General Surgery, İstanbul, Turkey

${ }^{3}$ Elitium Surgery Center, Department of General Surgery, İstanbul, Turkey

${ }^{4}$ University of Health Sciences Turkey, Bağcllar Training and Research Hospital, Clinic of Biochemistry, İstanbul, Turkey

5İstanbul University Faculty of Medicine, Department of General Surgery, İstanbul, Turkey

\section{Abstract}

Objective: The aim of this study was to determine the step-wise effects of vascular ligation method on the parathyroid function in intraoperative and early postoperative periods of total thyroidectomy.

Method: A total of 54 patients between the ages of 40 and 61 years, who underwent a total thyroidectomy for euthyroid multinodular goiter between June 2019 and December 2019, were included in this study. Thyroid lobes were separated step by step using the clamp-tie technique including an inferior approach, to preserve the parathyroid glands and recurrent laryngeal nerve. All patients underwent the same routine surgical and phlebotomy procedures. Serum parathyroid hormone (PTH) and Calcium $(\mathrm{Ca})$ levels were measured 2 hours before the operation, during the operation while the inferior and superior poles of the right and left lobe were connected, and at the $12^{\text {th }}$ postoperative hour, and all data were analyzed retrospectively.

Results: Of the 54 patients undergoing total thyroidectomy, 7 (12.9\%) were male and 47 (87.04\%) were female. The mean age was $45.65 \pm 8.23$ years. In terms of PTH measured in the intraoperative period, a statistically significant decrease was found during the vessel ligation of the superior pole of superior lobe, and lobe excision $(p<0.05)$. In the left lobe, an advanced decrease was detected after the vessel ligation of both poles and lobe excision $(p<0.001)$. When the serum levels of $C a$ were measured in the intraoperative period, there was no significant change during the

\section{Öz}

\begin{abstract}
Amaç: Vasküler ligasyon yönteminin, total tiroidektominin intraoperatif ve postoperatif erken dönemde paratiroid fonksiyonu üzerindeki aşamalı etkilerini belirlemek amaçlanmıştır.
\end{abstract}

Yöntem: Bu çalışmaya Haziran 2019 ile Aralık 2019 tarihleri arasında ötiroid multinodüler guatr nedeniyle total tiroidektomi uygulanan 40-61 yaşları arasında, toplam 54 hasta dahil edildi. Tiroid lobları, paratiroid bezleri ve rekürren laringeal sinir korunarak inferior yaklaşımlı klempbağlama tekniği kullanılarak adım adım ayrıldı. Tüm hastalara aynı cerrahi ve kan alma işlemi rutin olarak uygulandı. Serum paratiroid hormonu (PTH) ve Kalsiyum (Ca) düzeyleri operasyondan 2 saat önce, operasyon sırasında sağ ve sol lobun inferior ve superior polleri bağlandıkça ve postoperatif 12. saatte ölçüldü ve veriler retrospektif olarak incelendi.

Bulgular: Total tiroidektomi yapılan 54 hastanın 7'si $(\% 12,9)$ erkek ve 47 'si $(\% 87,04)$ kadındı, yaş ortalaması 45,65 8,23 idi. Intraoperatif dönemde PTH açısından olgular değerlendirildiğinde sağ lob superior pol damar ligasyonu ve lob eksizyonunda istatiksel olarak anlamlı azalma saptandı $(p<0,05)$. Sol lobda ise her iki pol damar ligasyonu ve eksizyonu sonrasında da ileri düzeyde azalma saptandı $(p<0,001)$. Serum $\mathrm{Ca}$ açısından incelendiğinde intraoperatif dönemde sağ lob cerrahi işlemlerinde anlamlı değişiklik saptanmazken, sol lob damar bağlama ve lob eksizyon işlemleri sonrası Ca düzeylerinde anlamlı düşme saptandı $(p<0,05)$. Postoperatif erken dönemde serum PTH ve Ca düzeylerinde

Address for Correspondence: Gülçin Ercan, University of Health Sciences Turkey, Bağcılar Training and Research Hospital, Clinic of General Surgery, İstanbul, Turkey

E-mail: ghepgul@hotmail.com ORCID: orcid.org/0000-0001-8420-9298 Received: 25.06.2020 Accepted: 31.08.2020

Cite this article as: Ercan G, Küçükyılmaz M, Yiğitbaş H, Hacım NA, Meriç S, Kuşaslan R, Altınel Y, Tokoçin M, Saraç T, Erbil Y. The Step Wise Effect of Vessel Ligation Method on Intra and Postoperative Hypoparathyroidism in the Total Thyroidectomy. Bagcilar Med Bull 2020;5(4):166-172

${ }^{\circ}$ Copyright 2020 by the Health Sciences University Turkey, Bagcilar Training and Research Hospital Bagcilar Medical Bulletin published by Galenos Publishing House. 


\section{Abstract}

surgical procedures of the right lobe, whereas there was a significant decrease after the vessel ligation of the left lobe and the lobe excision procedures $(p<0.05)$. There was a statistically significant decrease in serum PTH and Ca levels in the early post-operative period $(p<0.05)$. A significant decrease in PTH levels of patients without hypocalcemia was observed after ligation of the superior pole of the right lobe, whereas in patients with hypocalcemia, this decline started after the removal of the right lobe $(p<0.05)$. After the right lobe and left lobe excision and the $12^{\text {th }}$ postoperative hour, significant differences were detected in Ca levels between the groups with and without hypocalcemia. In addition, patients with hypocalcemia showed a significant decrease in Ca levels after left lobe excision and at the postoperative $12^{\text {th }}$ hour $(p<0.05$ and $p<0.001$, respectively).

Conclusion: The step-wise effects of the vessel ligation method on intraoperative and postoperative PTH levels in total thyroidectomy may vary depending on the presence of hypocalcemia without making a significant difference in the risk of early postoperative complications.

Keywords: Calcium, hypocalcemia, parathyroid hormone, total thyroidectomy

\section{Öz}

istatiksel olarak anlamlı azalma saptandı $(p<0,05)$. Sağ lobun superior polünün ligasyonu sonrası hipokalsemi olmayan hastaların PTH düzeylerinde anlamlı bir azalma gözlenirken, hipokalsemili hastalarda bu düşüş sağ lobun çıkarılmasından sonra başlamıştır $(p<0,05)$. Sağ lob ve sol lob eksizyonu sonrası ve postoperatif 12 . saatte, hipokalsemi olan ve olmayan gruplar arasında Ca düzeylerinde anlamlı farklar tespit edilmiştir. Ayrıca, hipokalsemili hastaların Ca düzeylerinde, sol lob eksizyonundan sonra ve postoperatif 12. saatte anlamlı düşüş görülmüştür (sırasıyla $p<0,05$ ve $p<0,001)$.

Sonuç: Total tiroidektomide konvansiyonel damar ligasyon yönteminin intraoperatif ve postoperatif PTH düzeylerine aşamalı etkilerinin, erken dönem postoperatif komplikasyon riski insidansında anlamlı bir fark yaratmadan, hipokalsemi varlığına bağlı olarak değişebileceği gösterilmiştir.

Anahtar kelimeler: Hipokalsemi, kalsiyum, paratiroid hormon, total tiroidektomi

\section{Introduction}

Thyroidectomy is a widely performed operation in the practice of general surgery and has a complication rate lower than 5\%. Nowadays, the most important complications of thyroidectomy performed mainly due to thyroid cancer and hyperparathyroidism are recurrent nerve injuries and transient or permanent hypoparathyroidism (1). In recent years, as the necessity of operation type includes the total thyroidectomies rather than subtotal types, the risk of these complications as well as the risks of incidental parathyroidectomy and related postoperative hypocalcemia increase in thyroidectomies (2). A statistically significant correlation was detected between incidental parathyroidectomy and hypocalcemia (3). Moreover, the bilateral thyroidectomy and central dissection also significantly increase the risk of developing postoperative hypocalcemia (4). Mastering the anatomy and knowing the anatomical variations are of primary importance, but parallel to the development in medical technologies, many hemostasis-producing techniques have also been developed (5-7). Although there are few studies in the literature about how these techniques including thermal devices result in any nerve injury and damage on the parathyroid glands (PGs), (7-9) the influence of vessel-ligation methods on intra and early postoperative PG function following a total thyroidectomy is not clear yet. In the present study, the stepwise effects of vascular ligation method on the parathyroid hormone (PTH) and Calcium (Ca) were investigated in the early and postoperative periods of total thyroidectomy by using an inferior approach and the results were discussed with the light of literature to elucidate the clinical outcomes of vessel ligation in thyroidectomy patients.

\section{Materials and Methods}

\section{Patients}

This study involved the data of 54 patients diagnosed with a euthyroid multinodular goiter operated by using an inferior approach, who were selected among 108 cases undergoing a total thyroidectomy in the Department of Surgery between June 2019 and December 2019. Prior to the study, the local ethics committee approval was obtained from the Clinical Research Ethics Committee of University of Health Sciences Turkey, Bağcllar Training and Research Hospital (decree number: 2020.01.1.05.005). All patients were informed about the study and informed consent was obtained from all patients regarding the use of their data in this scientific study.

The patients aged between 40 and 61 years, who were diagnosed as euthyroid multinodulargoiter and experienced a post-operative temporary hypoparathyroidism, were included in the study. The patients undergoing a combined thyroidectomy and parathyroidectomy and patients with the indications of papillary thyroid cancer, follicular cancer, anaplastic cancer, medullar cancer, hypothyroidism, hyperthyroidism, retrosternal goiter and toxic goiter were excluded from the study. Demographic data, the duration of operation, the day of hospitalization, the volume of drainage, the number of reoperations, and mortality rates 
were recorded.

\section{Operative Techniques}

Surgeries and postoperative care were standardized according to the literature $(10,11)$. All thyroidectomies were performed by using an inferior approach under general anesthesia, which was a routine practice firstly applied by the same experienced surgeons in our clinic. The thyroid was approached via a low transverse collar incision. After the elevation of the platysma flap, superiorly and inferiorly, the strap muscles were divided in the midline and elevated sharply from the underlying thyroid gland. The dissection of the thyroid began with ligation division of the middle thyroid vein. Ligations were done with resorbable 2-0 and 3-0 vicryl sutures. Attention was directed toward the visualization of the inferior and superior PGs. The inferior thyroid artery (ITA) was ligated after the identification of the recurrent laryngeal nerve (RLN), first the inferior pole vessels were ligated, then superior pole vessels were ligated. During the dissection of the PGs and RLN, we preferred suturing the small vessels in this area. Each suture-ligation used for this area (around Berry's ligament) and the thyroid tissue by its capsule were elevated from the pretracheal fascia carefully (10). The dissection was carried across the midline and completed by mobilizing the isthmus and pyramidal lobe of the thyroid $(10,11)$.

During the total thyroidectomy, the thyroid lobes of most patients were divided step by step by the inferior approach of clamp-tie technique, avoiding the PGs and RLNs. If there was any bleeding during the operation and the removal of tissue, the suture-ligation was used to provide hemostasis (10).

The duration of surgery was considered to be from the start of the skin incision until the wounds were covered with a dressing. Closure of the wound was performed using the conventional steps (11). Nerve monitoring system (Medtronic, NIM 3.0 version, USA) was used to monitor any nerve damage during the operation.

Serum PTH and Ca levels were preoperatively measured 2 hours before the operation, during the operation, and on the following 12 hours of the operation. Intraoperative levels of PTH and Ca were measured after the steps of the operation given below:

-Ligation of the inferior pole of the right lobe,

-Ligation of the superior pole of the right lobe,

-Excision of the right lobe,
-Ligation of the inferior pole of the left lobe,

-Ligation of the superior pole of the left lobe,

-Excision of the left lobe,

All data of the study were analyzed retrospectively.

\section{Laboratory Methods}

Intravenous blood samples of the patients were collected for eight times to measure the preoperative, intraoperative and postoperative serum PTH and albumin-adjusted Ca levels by standard methods using the Roche Diagnostics Modular Analytic system (Roche Diagnostics, Indianapolis, IN) in the biochemistry laboratory. PTH level was measured by an Elecsyse 170 immunoassay system, and the inter- and intra-assay CVs were $3.4 \%$ and $2 \%$, respectively. The normal range for serum PTH level was accepted to be between 10 and $65 \mathrm{pg} / \mathrm{mL}$. Hypocalcemia was defined as serum adjusted $\mathrm{Ca}<8.5 \mathrm{mg} / \mathrm{dL}$, measured within 24 hours of total thyroidectomy (range: $8.5-12.5 \mathrm{mg} / \mathrm{dL}$ ).

\section{Postoperative Management and Follow-up}

Postoperative complications including transient/ permanent RLN palsy, transient/permanent hypocalcemia, bleeding and wound infection were recorded. Postoperative diagnosis of hypocalcemia was not only due the blood level of $\mathrm{Ca}$, but also due to the clinical symptoms of hypocalcemia defined according to the literature (12). These symptoms include the neural hyperexcitability, confusion, disorientation, and hallucinations. On respiratory examination, inspiratory or expiratory wheeze, laryngeal stridor, dysphagia, and bronchospasm may be observed. On cardiac examination, bradycardia, tachycardia, S3, and signs of heart failure may be present. Chvostek signs and Trousseau signs may be indicative for hypocalcemia (12).

Oral $\mathrm{Ca}+$ calcitriol was not routinely given to all patients unless the level of adjusted Ca was under $8.5 \mathrm{mg} / \mathrm{dL}$, the level of PTH was lower than $10 \mathrm{pg} / \mathrm{mL}$ and the patients showed any postoperative clinical symptoms of hypocalcemia defined above. The patients with normal levels of PTH but with the level of adjusted Ca under $8.5 \mathrm{mg} / \mathrm{dL}$ with postoperative clinical symptoms of hypocalcemia were prescribed only two ampules of intravenous $\mathrm{Ca}$ (Ca Picken $10 \%$ ampule containing $225 \mathrm{mg}$ Ca Gluconate Monohydrate) twice within the first 24 hours. If the symptoms were not relieved, the injection of $\mathrm{Ca}$ was resumed. If needed, oral Ca (Calcimax-D3 ${ }^{\circledR}$ containing $2.500 \mathrm{mg}$ Ca carbonate and 880 IU vitamin D3, Basel Ilac, İstanbul, Turkey) and/ or oral calcitriol (Rocaltrol ${ }^{\circledR}$ containing $0.25 \mu \mathrm{g}$ calcitriol, Deva Ilac, İstanbul, Turkey) were prescribed twice daily 
until the first clinic visit. Patients requiring $\mathrm{Ca} \pm$ calcitriol supplements after their first postoperative visit were followed-up, and their $\mathrm{Ca}$ and PTH levels and clinical symptoms for hypocalcemia were checked until they could maintain normocalcemia and normoparathyroidism without supplements (13).

\section{Statistical Analysis}

All statistical analyses were performed by the GraphPad Instat Statistics Software. The normality test was performed by the Kolmogorov-Smirnow test. Two parametric data were compared by the Paired t-test, and two non-parametric data were compared by the Mann-Whitney U test. Three or more parametric data were compared by the ANOVA and Tukey-Kramer Multiple Comparisons test. Three or more non-parametric data were compared by the KruskalWallis test (non-parametric ANOVA) and Dunn's Multiple Comparisons test. The significance levels were determined as $\mathrm{p}<0.05, \mathrm{p}<0.01$, and $\mathrm{p}<0.001$.

\section{Results}

Of 54 patients who had undergone total thyroidectomy, 7 (12.9\%) were male and 47 (87.04\%) were female patients with an overall mean age of $45.65 \pm 8.23$ years (range: 40 61 years). There was no vocal cord paralysis (unilateral/ bilateral) following the surgery in any of the patients. The mean duration of operation was $110.2 \pm 8.9 \mathrm{~min}$ and that of hospitalization was $2.4 \pm 0.3$ days. The mean drainage volume was $50.2 \pm 9.3$. None of the patents needed any reoperation and no mortality due to the operation occurred. The most frequent postoperative complication was hypocalcemia that was transient in five patients $(9.3 \%)$, and there was no permanent hypocalcemia in any of the patients. Although the preoperative mean level of $\mathrm{Ca}$ of all patients appeared to be under normal range, not all patients showed the clinical symptoms of hypocalcemia; therefore, treatment for hypocalcemia was only applied to the patients with transient hypocalcemia. RLN palsy, bleeding or wound infection were not observed following the operation (Table 1).

Comparing preoperative, intraoperative and postoperative hormone levels of the patients (Table 2), a significant decrease in PTH levels started following the ligation of the superior pole of the right lobe $(\mathrm{p}<0.05)$ and this decrease continued until postoperative $12^{\text {th }}$ hour with an increasing level of significance depending on time and step of the operation. The lowest level of PTH was observed at the postoperative $12^{\text {th }}$ hour in comparison to the preoperative levels $(\mathrm{p}<0.001)$. On the other hand, Ca levels began to decrease following the ligation of the inferior pole of the left lobe $(\mathrm{p}<0.05)$ and this decrease also continued in time, and the lowest level of Ca was observed at the postoperative $12^{\text {th }}$ hour $(\mathrm{p}<0.001)$.

Patients were divided into subgroups according to the presence of hypocalcemia. No statistically significant intergroup difference was found among preoperative, intraoperative and postoperative PTH levels depending on the presence of hypocalcemia (Table 3). However, a considerable decrease in PTH levels of the patients without hypocalcemia was

\begin{tabular}{lll} 
Table 1. Postoperative parameters of the patients \\
Parameter & Value & Total $(\mathbf{n = 5 4 )}$ \\
\hline Operation duration (min) & Mean \pm SD & $110.2 \pm 8.9$ \\
Hospitalization (day) & Mean \pm SD & $2.4 \pm 0.3$ \\
Drainage volume (mL) & Mean \pm SD & $50.2 \pm 9.3$ \\
Reoperation & $\mathrm{n}(\%)$ & 0 \\
Mortality & $\mathrm{n}(\%)$ & 0 \\
Postoperative complications & $\mathrm{n}(\%)$ & - \\
Transient RLN palsy & - & 0 \\
Permanent RLN palsy & - & 0 \\
Transient hypocalcemia & - & $5(9.3)$ \\
Bleeding & - & 0 \\
Wound infection & - & 0
\end{tabular}

RLN: Recurrent laryngeal nerve, SD: Standard deviation

Table 2. Preoperative and postoperative hormone levels of the patients $(n=54)$

\begin{tabular}{|c|c|c|}
\hline & $\begin{array}{l}\text { Parathyroid } \\
\text { hormone } \\
\text { (pg/mL) } \\
\text { Mean } \pm \text { SEM }\end{array}$ & $\begin{array}{l}\text { Calcium } \\
(\mathrm{mg} / \mathrm{dL}) \\
\text { Mean } \pm \text { SEM }\end{array}$ \\
\hline Preoperative levels & $60.27 \pm 6.54$ & $7.32 \pm 0.16$ \\
\hline \multicolumn{3}{|l|}{ Intraoperative levels } \\
\hline $\begin{array}{l}\text { Ligation of the inferior pole of the } \\
\text { right lobe }\end{array}$ & $53.31 \pm 5.76$ & $7.25 \pm 0.18$ \\
\hline $\begin{array}{l}\text { Ligation of the superior pole of the } \\
\text { right lobe }\end{array}$ & $50.18 \pm 5.32 *$ & $7.19 \pm 0.16$ \\
\hline Excision of the right lobe & $47.55 \pm 3.98 *$ & $7.15 \pm 0.18$ \\
\hline $\begin{array}{l}\text { Ligation of the inferior pole of the } \\
\text { left lobe }\end{array}$ & $37.78 \pm 3.07^{* *}$ & $7.05 \pm 0.18^{*}$ \\
\hline $\begin{array}{l}\text { Ligation of the superior pole of the } \\
\text { left lobe }\end{array}$ & $35.20 \pm 3.36^{* * *}$ & $6.94 \pm 0.18^{*}$ \\
\hline Excision of the left lobe & $29.97 \pm 3.15^{* * *}$ & $6.70 \pm 0.17^{* * *}$ \\
\hline Postoperative $12^{\text {th }}$ hour & $19.99 \pm 2.11^{* * *}$ & $6.56 \pm 0.20^{* * *}$ \\
\hline $\mathbf{p}$ & 0.0001 & 0.0001 \\
\hline
\end{tabular}


observed following the ligation of the superior pole of the right lobe $(\mathrm{p}<0.01)$, while this decrease in the patients with hypocalcemia began after the removal of the right lobe $(\mathrm{p}<0.05)$. Reductions in PTH levels of both groups continued after the $12^{\text {th }}$ hour of the operation (Table 3).

Comparing the preoperative, intraoperative and postoperative $\mathrm{Ca}$ levels according to the presence of hypocalcemia (Table 4), a statistically significant difference was detected between two groups following the excision of the right lobe and the excision of the left lobe $(p<0.05)$. There was also a statistically notable difference among Ca levels of two groups at the postoperative $12^{\text {th }}$ hour of the operation $(\mathrm{p}<0.001)$, and additionally at that time, the lowest level of Ca was observed among the patients without hypocalcemia. Moreover, the patients with hypocalcemia had a significant decrease in Ca levels after the excision of the left lobe and at the postoperative $12^{\text {th }}$ hour of the operation $(\mathrm{p}<0.05$ and 0.001 , respectively).

\section{Discussion}

The most important complications of thyroid surgery with a great effect on the patient's quality of life are recurrent nerve injury and transient or permanent hypoparathyroidism $(5,6)$. A temporary hypoparathyroidism is common (24.1\%) but the permanent hypoparathyroidism is rare (1.2\%) following a total thyroidectomy (14). The most common cause of acquired hypoparathyroidism is the removal or devascularization of the PG due to a traumatic surgery (5). Thus, in the present study, the step-wise effects of vascular ligation method on the PG function were investigated in the early and postoperative periods of total thyroidectomy performed by using and inferior approach, and the findings showed a significant decrease in PTH levels following the ligation of the superior pole of the right lobe, which continued until the postoperative $12^{\text {th }}$ hour ever-increasingly, depending on the time and step of the operation; however, the levels of PTH were in normal range.

There are many studies investigating the effects of the selected surgical technique and vascular ligation methods

Table 3. Preoperative and postoperative parathyroid hormone levels $(\mathrm{pg} / \mathrm{mL})$ of the patients compared to the presence of hypocalcemia

\section{No hypocalcemia $(n=49) \quad$ Hypocalcemia $(n=5) \quad p$}

\begin{tabular}{|c|c|c|c|}
\hline Preoperative levels & $61.16 \pm 6.91$ & $51.80 \pm 7.03$ & 0.605 \\
\hline \multicolumn{4}{|l|}{ Intraoperative levels } \\
\hline Ligation of the inferior pole of the right lobe & $53.49 \pm 6.31$ & $51.60 \pm 2.71$ & 0.486 \\
\hline Ligation of the superior pole of the right lobe & $50.77 \pm 5.72$ & $44.52 \pm 4.48$ & 0.802 \\
\hline Excision of the right lobe & $47.89 \pm 4.22$ & $44.26 \pm 4.23$ & 0.808 \\
\hline Ligation of the inferior pole of the left lobe & $37.73 \pm 3.29 * *$ & $38.30 \pm 2.75$ & 0.757 \\
\hline Ligation of the superior pole of the left lobe & $35.68 \pm 3.52^{* *}$ & $30.68 \pm 3.99 *$ & 0.487 \\
\hline Excision of the left lobe & $29.92 \pm 3.44^{* * *}$ & $30.41 \pm 1.97 *$ & 0.487 \\
\hline Postoperative $12^{\text {th }}$ hour & $20.12 \pm 2.21^{* * *}$ & $18.74 \pm 2.50 *$ & 0.808 \\
\hline
\end{tabular}

*: $p<0.05, * *: p<0.01, * * *: p<0.001$ vs preoperative levels

\begin{tabular}{llll} 
& No hypocalcemia $(\mathbf{n = 4 9 )}$ & Hypocalcemia $(\mathbf{n = 5})$ & $\mathbf{p}$ \\
\hline $\begin{array}{l}\text { Preoperative levels } \\
\text { Intraoperative levels }\end{array}$ & $7.33 \pm 0.18$ & $7.20 \pm 0.08$ & 0.505 \\
Ligation of the inferior pole of the right lobe & $7.30 \pm 0.20$ & $6.80 \pm 0.34$ & 0.243 \\
Ligation of the superior pole of the right lobe & $7.24 \pm 0.17$ & $6.64 \pm 0.39$ & 0.318 \\
Excision of the right lobe & $7.22 \pm 0.19$ & $6.48 \pm 0.23$ & $0.029^{+}$ \\
Ligation of the inferior pole of the left lobe & $7.11 \pm 0.19$ & $6.44 \pm 0.64$ & 0.368 \\
Ligation of the superior pole of the left lobe & $7.00 \pm 0.19$ & $6.42 \pm 0.41$ & 0.247 \\
Excision of the left lobe & $6.78 \pm 0.19$ & $5.90 \pm 0.32^{*}$ & $0.047^{+}$ \\
Postoperative 12 & & $<.48 \pm 0.12^{* * *}$ \\
\hline
\end{tabular}

*: $p<0.05,{ }^{* *}: p<0.001$ vs preoperative levels, ${ }^{+}: p<0.05,{ }^{+++}: p<0.001$ vs no hypocalcemia 
on the PG in thyroidectomies, but there is no consensus on their superiority to each other $(7,8,11)$. Since we used only an inferior approach of clamp-tie technique for thyroidectomy and aimed to determine the changes in PTH and Ca levels, an iatrogenic damage on the PGs of patients can be excluded from our study. Although there are many studies predicting whether hypoparathyroidism will be temporary or permanent in which consensus on this issue cannot be reached $(15,16)$, we ignored these controversial ideas by selecting the patients without any hypoparathyroidism. We conducted this study on determining the indicative levels of PG function and hypocalcemia by excluding the thermal effect of devices completely and by entering to the thyroid gland by an inferior approach of clamp-tie and then performing all the hemostasis by vessel ligation. In this approach, the RLN is found in the soft areolar tissue in the tracheoesophageal groove proximal to the ITA crossing point. One advantage of this technique is that the RLN is found proximally prior to extra-laryngeal branching and away from thyroid bed scarring that might have been caused by prior surgery (10).

In the present study, the preoperative mean levels of $\mathrm{Ca}$ in all patients appeared to be lower than normal ranges. This is probably due to our patients experiencing a malnutrition or an insufficient sun exposure during a year, who live in a population with relatively low socioeconomical levels compared to the other regions of Turkey.

Studies have reported that there is no significant difference in safety and in terms of the risk of complications between a total thyroidectomy and subtotal thyroidectomy (17). Since the secondary interventions after a subtotal thyroidectomy may cause more damage to the parathyroid gland due to adhesions, we suggest performing the largest possible surgery, i.e. total thyroidectomy, in the first surgery. For this reason, we applied total thyroidectomy to all our patients. Some studies gave a high incidence of postoperative hypocalcemia by total thyroidectomy as $30 \%$ reported by de Araujo Filho et al. (18). However, this is still statistically different from the preoperative levels, as in our study in which Ca levels began to decrease following the ligation of the inferior pole of the left lobe and this decrease also continued by time and each step of the thyroidectomy, and the lowest level of Ca was observed at the postoperative $12^{\text {th }}$ hour. The enhanced decrease in Ca and PTH levels after the ligation of the left lobe was an expected outcome due to the removal of the right lobe, already performed before the removal of the left lobe.
Moreover, the most frequent postoperative complication was transient hypocalcemia observed in $9.3 \%$ of the patients, suggesting a lower risk of complication of hypocalcemia. Therefore, we may recommend a total thyroidectomy by using an inferior approach to all patients who are going to undergo a thyroidectomy.

Most researchers have claimed that the postoperative hypofunction of PGs occurs due to an ischemia, as a secondary to the ligation of the ITA. This is a logical inference, since it is well-known that the blood supply to the PGs glands comes mainly from this artery (18). Therefore, some studies evaluated the moderate influence of different surgical techniques in postoperative hypocalcemia and found the association of the distal ligation of ITA branches during a total thyroidectomy with lower mean postoperative Ca and PTH levels $(19,20)$. Although no conclusive results in favor of proximal or distal ligation have been reported, the distal ligation of ITA is a simple surgical maneuver, allowing to isolate carefully inferior parathyroid gland preserving the inferior laryngeal nerve. Therefore, we have always ligated the distal part of ITA, whereas a proximal ligation was also preferred in some cases, with a lower incidence. In these specific situations, the ligation of ITA along the main trunk is needed to achieve a better bleeding control, without any additional complication during surgery. This is promoted by the outcome of our study of the absence of any bleeding, besides the absence of RLN palsy and a wound infection, supporting a routine ligation of the distal part of ITA during a total thyroidectomy.

\section{Conclusion}

This study has shown that the step-wise effects of vessel ligation method on intra and early postoperative parathyroid functions following total thyroidectomy may vary based on the presence of hypocalcemia, without a significant difference in the incidence of risk of postoperative complications. The vessel ligation in thyroidectomy should be performed by a delicate manipulation of the thyroid glands by an experienced surgeon, and in the closest proximity of thyroid gland to preserve the PGs and their functions. If the parathyroid is removed or avulsed accidentally during the thyroidectomy, perioperative auto-implantation to the forearm or sternocleidomastoid muscle is suggested. In future studies, comparing the techniques of thyroidectomies is recommended, including an intraoperative identification of PGs or preoperative Ca supplementation to the patients with hypocalcemia. 


\section{Ethics}

Ethics Committee Approval: Prior to the study, the local ethics committee approval was obtained from the Clinical Research Ethics Committee of University of Health Sciences Turkey, Bağcllar Training and Research Hospital (decree number: 2020.01.1.05.005).

Informed Consent: All patients were informed about the study and informed consent was obtained from all patients regarding the use of their data in this scientific study.

Peer-review: Externally peer-reviewed.

\section{Authorship Contributions}

Concept: G.E., Y.E., Design: G.E., M.K., Y.E., Data Collection or Processing: G.E., H.Y., N.A.H., S.M., R.K., Y.A., M.T., T.S., Analysis or Interpretation: G.E., H.Y., N.A.H., S.M., R.K., Y.A., M.T., T.S., Literature Search: G.E., H.Y., N.A.H., S.M., Writing: G.E., M.K., H.Y., N.A.H., S.M., R.K., Y.A., M.T., T.S., Y.E.

Conflict of Interest: No conflict of interest was declared by the authors.

Financial Disclosure: The authors declared that this study has received no financial support.

\section{References}

1. Grajek ZW, Dadan J, Ładny JR, Opolski M. The assessment of the influence of the method for obtaining hemostasis on the occurrence of postoperative complications after thyroid surgery. Adv Clin Exp Med 2015;24(2):275-278.

2. Ozoğul B, Akçay MN, Kisaoğlu A, Atamanalp SS, Oztürk G, Aydinli B. Incidental parathyroidectomy during thyroid surgery: risk factors, incidence, and outcomes. Turk J Med Sci 2014;44(1):84-88.

3. Noureldine SI, Genther DJ, Lopez M, Agrawal N, Tufano RP. Early predictors of hypocalcemia after total thyroidectomy: an analysis of 304 patients using a short-stay monitoring protocol. JAMA Otolaryngol Head Neck Surg 2014;140(11):1006-1013.

4. Ozemir IA, Buldanli MZ, Yener O, Leblebici M, Eren T, Baysal H, et al. Factors affecting postoperative hypocalcemia after thyroid surgery: Importance of incidental parathyroidectomy. North Clin Istanb 2016;3(1):9-14.

5. Wang JB, Sun HL, Song CY, Gao L. Association between decreased serum parathyroid hormone after total thyroidectomy and persistent hypoparathyroidism. Med Sci Monit 2015;21:1223-1231.

6. Sławeta N, Głuszek S. Effect of complicated thyroid surgical procedures on personal and professional life of patients. Pol Przegl Chir 2012;84(9):437-444.
7. Yao HS, Wang Q, Wang WJ, Ruan CP. Prospective clinical trials of thyroidectomy with LigaSure vs conventional vessel ligation: a systematic review and meta-analysis. Arch Surg 2009;144(12):11671174 .

8. Brzeziński J, Kałużna-Markowska K, Naze M, Stróżyk G, Dedecjus M. Comparison of lateral thermal spread using monopolar and bipolar diathermy, and the bipolar vessel sealing system ThermoStapler ${ }^{\mathrm{TM}}$ during thyroidectomy. Pol Przegl Chir 2011;83(7):355-360.

9. Cakabay B, Sevinç MM, Gömceli I, Yenidogan E, Ulkü A, Koç S. LigaSure versus clamp-and-tie in thyroidectomy: a single-center experience. Adv Ther 2009;26(11):1035-1041.

10. Butskiy O, Chang BA, Luu K, McKenzie RM, Anderson DW. A systematic approach to the recurrent laryngeal nerve dissection at the cricothyroid junction. J Otolaryngol Head Neck Surg 2018;47(1):57.

11. Khafagy AH, Abdelnaby I. Total thyroidectomy: Ligasure versus Clamp \& Knot technique for intraoperative hemostasis. EJENTAS 2013;14(2):59-65.

12. Murphy G, Bartle S. Hypocalcemic laryngospasm and tetany in a child with renal dysplasia. Pediatr Emerg Care 2006;22(7):507-509.

13. Luo H, Yang H, Wei T, Gong Y, Su A, Ma Y, et al. Protocol for management after thyroidectomy: a retrospective study based on one-center experience. Ther Clin Risk Manag 2017;13:635-641.

14. Asari R, Passler C, Kaczirek K, Scheuba C, Niederle B. Hypoparathyroidism after total thyroidectomy: a prospective study. Arch Surg 2008;143(2):132-137.

15. Hermann M, Ott J, Promberger R, Kober F, Karik M, Freissmuth M. Kinetics of serum parathyroid hormone during and after thyroid surgery. Br J Surg 2008;95(12):1480-1487.

16. Uludağ M, Besler E, Aygün N, Çitgez B, Mihmanlı M, Yetkin SG, et al. The factors affecting the occurance of hypocalcemia after thyroid surgery. SETB 2015;49(2):101-106.

17. Girgin S, Gümüs M, Önder A, Kapan M. Completion thyroidectomy: Results of a single center. Dicle Med J 2009;36(3):165-169.

18. de Araujo Filho VJ, e Silva Filho GB, Brandão LG, dos Santos LR, Ferraz AR. The importance of the ligation of the inferior thyroid artery in parathyroid function after subtotal thyroidectomy. Rev Hosp Clin Fac Med Sao Paulo 2000;55(4):113-120.

19. Romano G, Scerrino G, Profita G, Amato G, Salamone G, Di Buono $G$, et al. Terminal or truncal ligation of the inferior thyroid artery during thyroidectomy? A prospective randomized trial. Int J Surg 2016;28(Suppl 1):S13-S16.

20. Antakia R, Edafe O, Uttley L, Balasubramanian SP. Effectiveness of preventative and other surgical measures on hypocalcemia following bilateral thyroid surgery: a systematic review and metaanalysis. Thyroid 2015;25(1):95-106. 